\title{
Protocol for Apoptosis Assay by Flow Cytometry Using Annexin V Staining Method
}

Imayavaramban Lakshmanan and Surinder K Batra*

Biochemistry and Molecular Biology, Nebraska Medical Center, Omaha, USA

*For correspondence: sbatra@unmc.edu

[Abstract] This assay is used to count the number of cells that have undergone apoptosis. Apoptosis will be detected by initially staining the cells with Annexin $\mathrm{V}$ and propidium lodide solution followed by flow cytometry analysis. It is based on the principle that normal cells are hydrophobic in nature as they express phosphatidyl serine in the inner membrane (side facing the cytoplasm) and when the cells undergo apoptosis, the inner membrane flips to become the outer membrane, thus exposing phosphatidyl serine. The exposed phosphatidyl serine is detected by Annexin $\mathrm{V}$, and propidium iodide stains the necrotic cells, which have leaky DNA content that help to differentiate the apoptotic and necrotic cells.

\section{Materials and Reagents}

1. Annexin V FLUOS staining kit (F. Hoffmann-La Roche, catalog number: 11858777001)

2. The kit contains ready-to-use Annexin-V-FLUOS solution, propidium iodide solution, and incubation buffer

3. Trypsin

4. $\mathrm{NaCl}$

5. $\mathrm{KCl}$

6. $\mathrm{Na}_{2} \mathrm{HPO}_{4}$

7. $\mathrm{KH}_{2} \mathrm{PO}_{4}$

8. PBS buffer (pH 7.4) (see Recipes)

\section{Equipment}

1. Flow cytometer

2. Centrifuge

3. T25 culture flask

\section{Procedure}

1. Seed cells $\left(1 \times 10^{6}\right.$ cells) in a T25 culture flask (in triplicate for experiments) and three 
T25 culture flask for control (unstained, Annexin only, and propidium iodide only).

2. After $48 \mathrm{~h}$ incubation, collect the supernatant (floating apoptotic cells) and trypsinize the adherent cells $\left(\sim 2 \times 10^{6}\right.$ cells) from each T25 flask (combine respective floating and trypsinized cells resulting in six tubes).

3. Wash the collected cells twice with PBS and centrifuge ( $670 \times g, 5 \mathrm{~min}, \mathrm{RT})$.

4. Re-suspend each pellet $\left(\sim 2 \times 10^{6}\right.$ cells $)$ in PBS $(400 \mu \mathrm{l})$.

For experimental cells (Triplicate) - $(400 \mu \mathrm{l}$ of cells $+100 \mu \mathrm{l}$ of incubation buffer with $2 \mu \mathrm{l}$ of Annexin [1 mg/ml] and $2 \mu \mathrm{l}$ of propidium iodide [1 mg/ml]).

For control cells

Control 1: (unstained) - (without any stain $(400 \mu$ of cells $+100 \mu$ of incubation buffer)

Control 2: (Annexin $V$ only) $-(400 \mu$ of cells $+100 \mu$ of incubation buffer with $2 \mu$ of Annexin $(1 \mathrm{mg} / \mathrm{ml}))$

Control 3: (propidium iodide only) - $(400 \mu \mathrm{l}$ of cells $+100 \mu \mathrm{l}$ of incubation buffer with $2 \mu \mathrm{l}$ of propidium iodide $(1 \mathrm{mg} / \mathrm{ml})$ )

5. Analyze the cells using a flow cytometry without washing the cells

Cells that were propidium iodide $(\mathrm{PI})$ negative and Annexin $\mathrm{V}$ negative are considered healthy, cells, PI negative and Annexin $V$ positive cells are considered apoptotic, and cells that are positive to both $\mathrm{PI}$ and Annexin $\mathrm{V}$ considered necrotic (Figure 1).

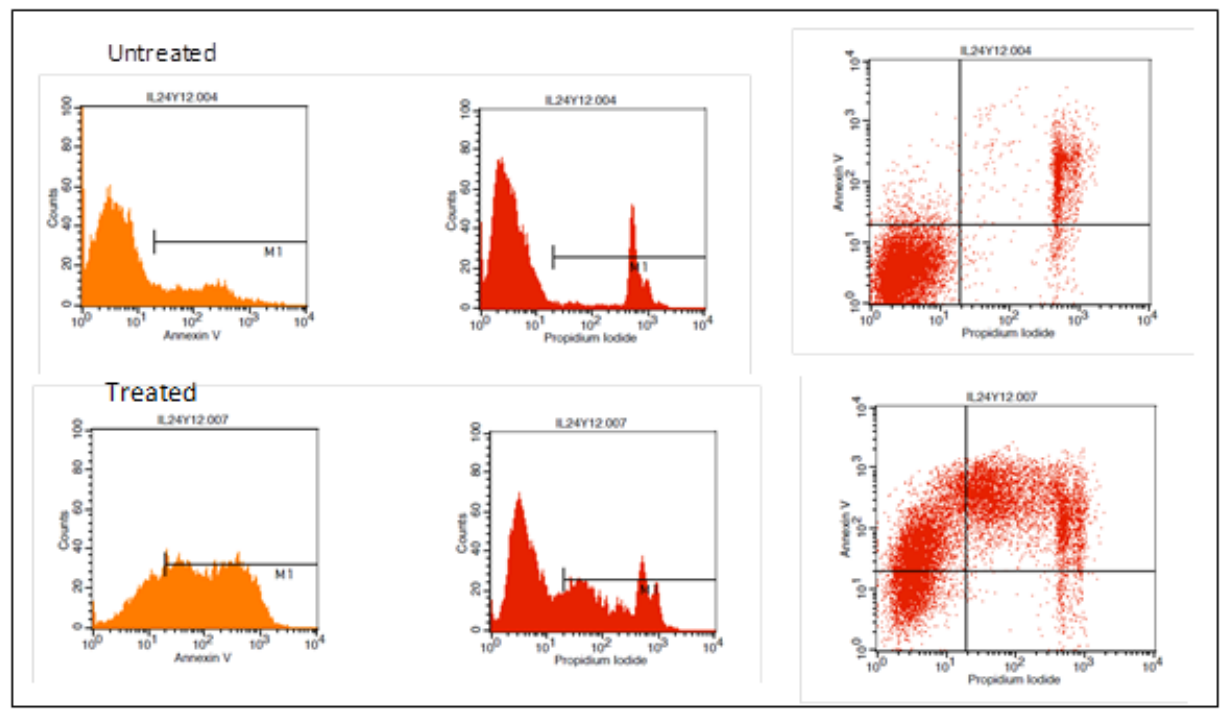

Figure 1.

\section{Recipes}

1. PBS buffer ( $\mathrm{pH} 7.4)$

$8 \mathrm{~g} \mathrm{NaCl}$ 
$0.2 \mathrm{~g} \mathrm{KCl}$

$2.3 \mathrm{~g} \mathrm{Na}_{2} \mathrm{HPO}_{4}$

$0.22 \mathrm{~g} \mathrm{KH}_{2} \mathrm{PO}_{4}$

In $800 \mathrm{ml}$ of distilled $\mathrm{H}_{2} \mathrm{O}$ adjust the $\mathrm{pH}$ to 7.4 .

\section{Acknowledgments}

The authors thank Dr. Palanimuthu Ponnusamy Moorthy and Dr. Dhanya Haridas for critical reading of the apoptosis experimental protocol. We also thank Philip Hexley and Victoria Smith, Flow Cytometry Research Facility at UNMC, for their support.

\section{References}

1. Lakshmanan, I., M. P. Ponnusamy, S. Das, S. Chakraborty, D. Haridas, P. Mukhopadhyay, S. M. Lele and S. K. Batra (2012). MUC16 induced rapid G2/M transition via interactions with JAK2 for increased proliferation and anti-apoptosis in breast cancer cells. Oncogene 31(7): 805-817. 